\title{
Risk factors for losing hepatitis $B$ virus surface antibody in patients with HBV surface antigen negative/surface antibody positive serostatus receiving biologic disease-modifying anti-rheumatic drugs: a nested case-control study
}

Ming-Hui Hung ${ }^{1}$, Ya-Chih Tien ${ }^{1}$ and Ying-Ming Chiu ${ }^{2^{*}}$ (D)

\begin{abstract}
Background: Hepatitis B virus (HBV) reactivation consequent to immunosuppressive therapy is an increasingly prevalent problem with serious clinical implications. Treatment with biologic agents conduces to the loss of protective antibody to HBV surface antigen (anti-HBs), which significantly increases the risk of HBV reactivation. Hence, we investigated the risk factors for losing anti-HBs in patients with rheumatic diseases and HBV surface antigen negative/anti-HBs positive ( $\mathrm{HBsAg}$-/anti-HBs+) serostatus during treatment with biologic disease-modifying anti-rheumatic drugs (DMARDs).

Methods: Using a nested case-control design, we prospectively enrolled patients with rheumatoid arthritis, ankylosing spondylitis, psoriatic arthritis/psoriasis, or juvenile idiopathic arthritis, who were treated with biologic DMARDs at Changhua Christian Hospital, Taiwan, from January 2013 to June 2019 and had HBsAg-/anti-HBs+ serostatus; the analytic sample excluded all patients with $\mathrm{HBsAg}+$ or anti-HBs-serostatus. Anti-HBs titers were monitored 6-monthly and cases were defined as anti-HBs $<10 \mathrm{mlU} / \mathrm{ml}$ during follow-up. Cases were matched oneto-all with controls with anti-HBs $\geq 10 \mathrm{mlU} / \mathrm{ml}$ on the same ascertainment date and equivalent durations of biologic DMARDs treatment (control patients could be resampled and could also become cases during follow-up). Between-group characteristics were compared and risk factors for anti-HBs loss were investigated by conditional logistic regression analyses.

\footnotetext{
* Correspondence: ymcgreen@yahoo.com.tw
}

2Department of Allergy, Immunology, and Rheumatology, Tungs' Taichung MetroHarbor Hospital, 699, Sec. 8, Taiwan Blvd., Taichung City 43503, Taiwan Full list of author information is available at the end of the article

(c) The Author(s). 2021 Open Access This article is licensed under a Creative Commons Attribution 4.0 International License, which permits use, sharing, adaptation, distribution and reproduction in any medium or format, as long as you give appropriate credit to the original author(s) and the source, provide a link to the Creative Commons licence, and indicate if changes were made. The images or other third party material in this article are included in the article's Creative Commons licence, unless indicated otherwise in a credit line to the material. If material is not included in the article's Creative Commons licence and your intended use is not permitted by statutory regulation or exceeds the permitted use, you will need to obtain permission directly from the copyright holder. To view a copy of this licence, visit http://creativecommons.org/licenses/by/4.0/. 
(Continued from previous page)

Results: Among 294 eligible patients, 23 cases were matched with 311 controls. The incidence of anti-HBs loss was $\sim 2.7 \%$ /person-year during biologic DMARDs treatment. Besides lower baseline anti-HBs titer (risk ratio 0.93, 95\% Cl 0.89-0.97), cases were significantly more likely than controls to have diabetes mellitus (risk ratio $4.76,95 \%$ Cl $1.48-$ 15.30) and chronic kidney disease (risk ratio 14.00, 95\% Cl 2.22-88.23) in univariate analysis. Risk factors remaining significantly associated with anti-HBs loss in multivariate analysis were lower baseline anti-HBs titer (adjusted risk ratio $0.93,95 \% \mathrm{Cl}$ 0.88-0.97) and chronic kidney disease (adjusted risk ratio 45.68, 95\% Cl 2.39-871.5).

Conclusions: Besides lower baseline anti-HBs titer, chronic kidney disease also strongly predicts future anti-HBs negativity in patients with $\mathrm{HBs} A g-/ a n t i-H B s+$ serostatus who receive biologic DMARDs to treat rheumatic diseases. Patients with low anti-HBs titer $(\leq 100 \mathrm{mlU} / \mathrm{ml})$ and/or chronic kidney disease should be monitored during biologic DMARDs therapy, to enable timely prophylaxis to preempt potential HBV reactivation.

Keywords: Hepatitis B virus (HBV), HBV surface-antigen negative/surface antibody positive (HBsAg-/anti-HBs+), Rheumatic diseases, Biologic disease-modifying anti-rheumatic drug (DMARD), Anti-HBs loss, Chronic kidney disease

\section{Background}

Hepatitis B virus (HBV) infection is a global public health concern [1]. Morbid HBV reactivation is characterized by viral replication and the recurrence of active necroinflammatory liver disease, which may presage severe hepatitis or even death [1-6]. Rising prevalence of cancer and autoimmune diseases and more frequent use of chemotherapeutic or immunosuppressive treatment strategies, have made $\mathrm{HBV}$ reactivation consequent to such therapies an exigent problem [1-5]. Iatrogenic HBV reactivation is best known in HBV surface-antigen carriers $(\mathrm{HBsAg}+)$, and comprehensive guidelines cover this highrisk group [1-8]. Recently, attention has increasingly focused on patients who are HBsAg-negative with antibodies against $\mathrm{HBV}$ core-antigen or surface-antigen (HBsAg-/anti-HBc+ or anti-HBs+), among whom baseline HBV DNA and anti-HBs negative (anti-HBs-) serostatus are known risk factors for $\mathrm{HBV}$ reactivation [9-13].

Although serum HBV DNA is a defining characteristic of $\mathrm{HBV}$ reactivation [1-4], it does not inevitably progress to morbid viremia but may manifest transiently without symptoms, especially whilst anti-HBs serostatus remains positive $[5,6,10-12]$. On the other hand, antiHBs loss consequent to immunosuppressive treatment

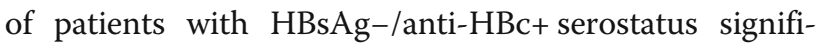
cantly increases the risk of progression from clinically silent to symptomatic HBV reactivation [9, 10, 12, 13]. Previous studies have shown that anti-HBs can decline to seronegative during immunosuppressive therapies, especially in patients with a low baseline anti-HBs titer $[11,14]$, but none have systematically investigated whether there are other predisposing factors.

In this context, especially given burgeoning use of tumor necrosis factor inhibitors (anti-TNF) and other biologic disease-modifying anti-rheumatic drugs (DMARDs) to treat autoimmune diseases, and elevated HBV reactivation rates in this setting $[2,4,5]$, it is imperative to further elucidate risk factors for anti-HBs loss. To this end, we prospectively studied patients with $\mathrm{HBsAg}-/ \mathrm{anti}-\mathrm{HBc}+$ serostatus during/after biologic DMARDs therapy for rheumatic diseases.

\section{Methods \\ Study subjects}

The study sample comprised patients at Changhua Christian Hospital, Taiwan, with rheumatoid arthritis, ankylosing spondylitis, psoriasis, psoriatic arthritis, or juvenile idiopathic arthritis, who were treated with biologic DMARDs from January 2013 to June 2019. Only patients with $\mathrm{HBsAg-/anti-HBs}+$ serostatus were included and all with HBsAg+ or HBsAg-/antiHBs-serostatus were excluded (Fig. 1). All study subjects fulfilled international diagnostic criteria for these diseases and were treated according to Taiwan Rheumatology Association guidelines for screening and management of viral hepatitis [15].

\section{Hepatitis B serologic testing and HBV DNA}

HBV serology and DNA assays were done every 6 months according to Taiwan Rheumatology Association recommendations [15]. HBV assays included serum $\mathrm{HBsAg}$, anti-HBs and anti-HBc, measured by Architect i2000SR chemiluminescent microparticle immunoassay (Abbott Laboratories, Abbot Park, Illinois, USA). HBV immunization history of people with anti-HBs+/anti$\mathrm{HBc}$ - serostatus was not ascertained.

Anti-HBs titer $<10 \mathrm{mIU} / \mathrm{ml}$ was defined as seronegative. Low anti-HBs titer was defined as 10-100 $\mathrm{mIU} / \mathrm{ml}$, based on evidence of significantly increased likelihood of anti-HBs loss and detectable HBV DNA at anti-HBs titers below $100 \mathrm{mIU} / \mathrm{ml}$ and protection against $\mathrm{HBV}$ reactivation above this threshold [11, 14]. Serum HBV DNA viral load was quantified by Abbott RealTime HBV (Abbott Laboratories, Abbott Park, Illinois, USA), with a minimal sensitivity of 10 $\mathrm{IU} / \mathrm{ml}$. HBV DNA titer $\geq 10 \mathrm{mIU} / \mathrm{ml}$ was defined as 


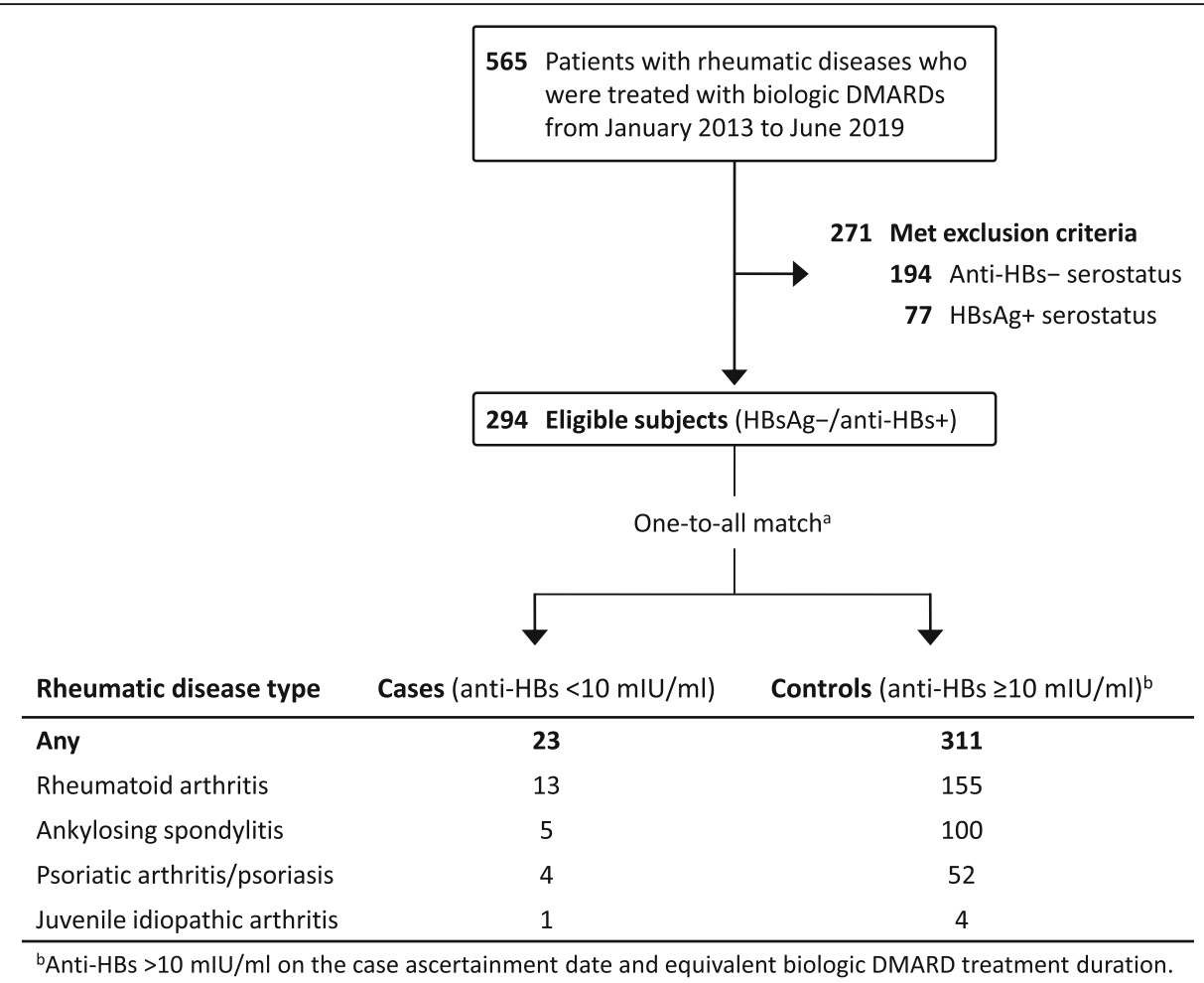

Fig. 1 Case-control selection flow chart. DMARDs, disease-modifying anti-rheumatic drugs; HBV, hepatitis B virus; DNA, deoxyribonucleic acid; anti-HBs, HBV surface antibody; HBsAg, HBV surface-antigen; mIU, million International Units. ${ }^{\mathrm{a}}$ One patient could serve as a control repeatedly during follow-up and control subjects could become cases during the study

detectable viral load [11], while the criteria defining clinical HBV reactivation at any serial 6-monthly follow-up check, were HBV replication $\geq 2 \log$ increase from baseline or a new appearance of HBV DNA to $\geq 100 \mathrm{IU} / \mathrm{ml}$ in people with previously stable or undetectable levels [1].

\section{Covariate information}

Baseline data included: age, sex, type of rheumatic disease (rheumatoid arthritis, ankylosing spondylitis, psoriatic arthritis/psoriasis, juvenile idiopathic arthritis), accumulated doses of conventional DMARDs (prednisolone, hydroxychloroquine, sulfasalazine, methotrexate, leflunomide, cyclosporine) and biologic DMARDs (etanercept, adalimumab, golimumab, ustekinumab, secukinumab, tocilizumab, rituximab, abatacept, tofacitinib). Chronic kidney disease was defined as estimated glomerular filtration rate $<60 \mathrm{ml} / \mathrm{min} /$ $1.73 \mathrm{~m}^{2}$. Chronic liver disease status was determined from medical charts or hepatic ultrasound results and included cirrhosis, fatty liver, and "parenchymal liver disease", which is a term used in Taiwan, to denote ultrasound findings intermediate between "normal" and "cirrhosis", based on sonographic evaluation criteria for liver surface, liver parenchyma, hepatic vessels, and spleen size [16].

\section{Nested case-control design}

We used a nested case-control design, which enables efficient analysis of time-dependent exposures on rare outcomes where only a limited sample from a larger population is practical, without compromising statistical power [17-19]. Unlike conventional cohort studies, which compare cases versus controls from a fully enumerated population, a nested case-control design identifies occurrences of events of interest in a defined sub-population and matches these with a specified number of control subjects drawn from the same sub-sample, but who were not yet affected by the same event when it occurred in their corresponding case $[18,19]$. This design means that controls can become cases later during follow-up and that each patient may serve as a control repeatedly (though at different times); thus, cases are compared with controls from the same patient sample, which lessens the likelihood of selection bias [17-20].

The first prescription of a biologic DMARD defined the start point. Cases were defined upon occurrences of serum anti-HBs titer $<10 \mathrm{mIU} / \mathrm{ml}$ during follow-up, with the 
date when anti-HBs loss was ascertained designated the event date. Each case was matched one-to-all with subjects whose serum HBsAb titer was $\geq 10 \mathrm{mIU} / \mathrm{ml}$ on the respective case ascertainment date and who had an equivalent duration of biologic DMARDs treatment.

\section{Data analysis and statistics}

All analyses were done using nonparametric statistical software (LogXact 11, Cytel Software Corp, Cambridge, MA, USA) with penalized maximum likelihood to remove first-order bias. A $p$-value $<0.05$ for two-sided tests was considered statistically significant. Continuous variables were expressed as means plus/minus standard deviation or mean [range], categorical variables as numbers (percentages). Conditional logistic regression analysis was used to estimate risk ratios and 95\% confidence intervals for loss of anti-HBs; putative associated factors included age, sex, type of rheumatic disease, conventional DMARDs, biologic DMARDs (anti-TNF or others), comorbidity, and baseline anti-HBs titer.

\section{Results}

\section{Demographic characteristics and clinical status}

The analytic samples drawn from 294 patients with HBsAg-/anti-HBs+ serostatus at baseline, comprised 23 cases and 311 matched controls (Fig. 1); Table 1 shows their demographic and clinical characteristics. Mean age and rheumatic disease types were similar between case and control groups. No patients with $\mathrm{HBsAg}$-/antiHBs+ serostatus had detectable HBV DNA at enrolment. Compared with controls, cases had lower baseline serum anti-HBs titers, more prevalent comorbidities (including hepatitis $\mathrm{C}$ virus infection, chronic liver disease, diabetes mellitus, chronic kidney disease), and relatively higher accumulated doses of sulfasalazine, leflunomide, and prednisolone. Most people in both groups used antiTNF agents (etanercept, adalimumab, golimumab). No study subjects were kidney transplant recipients.

\section{Incidence of anti-HBs loss and associated risk factors}

The incidence rate of anti-HBs loss in 294 patients with $\mathrm{HBsAg}-$ /anti-HBs+ serostatus during biologic DMARDs treatment was $23 / 852$ person-years: $\sim 2.7 \%$ /person-year.

Table 2 shows risk factors associated with loss of antiHBs in univariate and multivariate conditional logistic regression analyses. Besides lower baseline anti-HBs titer (risk ratio $0.93,95 \%$ CI 0.89-0.97), cases were significantly more likely than controls to have diabetes mellitus (risk ratio 4.76, 95\% CI 1.48-15.30) and chronic kidney disease (risk ratio 14.00, 95\% CI 2.22-88.23) in the univariate analysis. However, the only factors remaining significant in the multivariate model, were lower baseline serum anti-HBs titer (adjusted risk ratio 0.93, 95\% CI
0.88-0.97) and chronic kidney disease (adjusted risk ratio $45.68,95 \%$ CI $2.39-871.5$ ).

\section{Clinical features and outcomes of subjects with anti-HBs loss}

Thirteen cases had rheumatoid arthritis (Table 3). All cases' baseline anti-HBs titers were low $(\leq 100 \mathrm{mIU} / \mathrm{ml})$, mean 22.6. Fourteen were prescribed anti-TNF agents: four etanercept, six adalimumab, and four golimumab. Three were prescribed tofacitinib. Two cases each were prescribed ustekinumab or tocilizumab, while one each received abatacept or rituximab.

No cases (nor anti-HBs+ controls) had clinical HBV reactivation during follow-up (852 person-years), and no cases developed alanine transaminase elevation, or received any anti-viral treatment during median follow-up of 30 months (range 0-77) after anti-HBs loss. Only one of the $16 / 23$ cases whose serum HBV DNA was monitored after anti-HBs loss ever had a detectable viral load (Table 3), which was observed only once, with no recurrence as of August 2020.

\section{Discussion}

We believe this to be the first report of risk factors associated with loss of anti-HBs in rheumatic patients during biologic DMARDs therapy, after controlling for putative risk factors. We discovered that besides lower baseline anti-HBs titer, chronic kidney disease independently predicts anti-HBs loss.

Our finding that lower pretreatment anti-HBs titer $(\leq 100 \mathrm{mIU} / \mathrm{ml})$ is a risk factor for loss of anti-HBs, is consistent with a study of rituximab-based therapy for lymphoma [14]. Moreover, baseline anti-HBs positivity was protective against $\mathrm{HBV}$ reactivation among patients with $\mathrm{HBsAg}-/ \mathrm{anti}-\mathrm{HBc}+$ serostatus who received immunosuppressive or biologic agents [9-14]. Therefore, our results suggest that anti-HBs may be lost during/after immunosuppressive/biologic therapy, especially in people with a low baseline titer, with consequently elevated risk of HBV reactivation.

Although we detected no cases of morbid viremia and just one occurrence of minimal HBV DNA during follow-up, this was not necessarily inconsistent with evidence that anti-HBs negativity increases the risk of HBV reactivation in patients with $\mathrm{HBsAg}-/ \mathrm{anti}-\mathrm{HBC}+$ serostatus. Anti-HBs may remain persistently low or negative during treatment, with HBV DNA detected periodically but without progression to morbid reactivation $[5,6,11$, 12]. Reported rates of HBV DNA manifestation during/ after immunosuppressive therapy in patients with

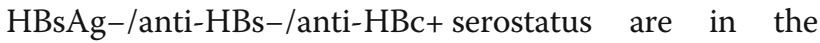
order of $1-10 \%$, with symptomatic reactivation in a smaller fraction of cases [9-12]; therefore, 23 cases may have been too few to detect occasional reactivation 
Table 1 Baseline characteristics of cases and controls treated with biologic DMARDs

\begin{tabular}{|c|c|c|}
\hline Data show mean \pm standard deviation, mean [range], or number (\%) & Cases & Controls \\
\hline Number & 23 & 311 \\
\hline Age (years) & $52.2 \pm 17.9$ & $47.5 \pm 14.2$ \\
\hline \multicolumn{3}{|l|}{ Sex } \\
\hline Female & $15(65.2 \%)$ & $148(47.6 \%)$ \\
\hline Male & $8(34.8 \%)$ & $163(52.4 \%)$ \\
\hline \multicolumn{3}{|l|}{ Rheumatic disease } \\
\hline Rheumatoid arthritis & $13(56.5 \%)$ & $155(49.8 \%)$ \\
\hline Ankylosing spondylitis & $5(21.7 \%)$ & $100(32.2 \%)$ \\
\hline Psoriatic arthritis/Psoriasis & $4(17.4 \%)$ & $52(16.7 \%)$ \\
\hline Juvenile idiopathic arthritis & $1(4.4 \%)$ & $4(1.3 \%)$ \\
\hline Detectable HBV DNA ( $\geq 10 \mathrm{IU} / \mathrm{ml})$ & 0 & 0 \\
\hline Anti-HBV core antigen positive & $15(65.2 \%)$ & $189(60.8 \%)$ \\
\hline \multicolumn{3}{|l|}{ Baseline serum anti-HBs titer (mIU/ml) } \\
\hline Mean [Min-Max] & $22.6[10.1-64.7]$ & $284.5[11.5-1000]^{\mathrm{a}}$ \\
\hline$\leq 100$ & $23(100 \%)$ & $128(41.2 \%)$ \\
\hline$>100$ & 0 & $183(58.8 \%)$ \\
\hline \multicolumn{3}{|l|}{ Biologic DMARDs } \\
\hline Anti-TNF (Etanercept, Adalimumab, Golimumab) & $14(60.9 \%)$ & $231(74.3 \%)$ \\
\hline Not anti-TNF & $9(39.1 \%)$ & $80(25.7 \%)$ \\
\hline Abatacept & $1(4.4 \%)$ & $11(3.5 \%)$ \\
\hline Rituximab & $1(4.4 \%)$ & $11(3.5 \%)$ \\
\hline Tocilizumab & $2(8.7 \%)$ & $12(3.9 \%)$ \\
\hline Tofacitinib & $3(13.0 \%)$ & 19 (6.1\%) \\
\hline Ustekinumab & $2(8.7 \%)$ & $25(8.0 \%)$ \\
\hline Secukinumab & 0 & $2(0.6 \%)$ \\
\hline \multicolumn{3}{|l|}{ Conventional DMARDs (accumulated dose) } \\
\hline Methotrexate (mg) & $536 \pm 869$ & $537 \pm 734$ \\
\hline Leflunomide (mg) & $748 \pm 2083$ & $707 \pm 3021$ \\
\hline Sulfasalazine (g) & $350 \pm 354$ & $242 \pm 318$ \\
\hline Hydroxychloroquine (g) & $67 \pm 102$ & $54 \pm 100$ \\
\hline Cyclosporine (g) & $9 \pm 22$ & $8 \pm 27$ \\
\hline Prednisolone (accumulated dose, mg) & $2244 \pm 2614$ & $1422 \pm 1910$ \\
\hline \multicolumn{3}{|l|}{ Comorbidities } \\
\hline Prior alanine transaminase elevation ${ }^{b}$ & $2(8.7 \%)$ & $10(3.2 \%)$ \\
\hline Hepatitis C virus antibody positive & $2(8.7 \%)$ & $11(3.5 \%)$ \\
\hline Diabetes mellitus & $4(17.4 \%)$ & $12(3.9 \%)$ \\
\hline Chronic liver disease & $5(21.7 \%)$ & $30(9.7 \%)$ \\
\hline Chronic kidney disease & $3(13.0 \%)$ & $3(1.0 \%)$ \\
\hline
\end{tabular}

HBV Hepatitis B virus, DNA Deoxyribonucleic acid, Anti-HBs HBV surface antibody, IU International Units, DMARD Disease-modifying anti-rheumatic drug, TNF Tumor necrosis factor

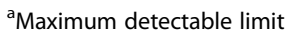

${ }^{\mathrm{b}}$ More than five-fold upper reference of $40 \mathrm{IU} / \mathrm{L}$

events. The follow-up duration (median 30 months after anti-HBs loss) may also have been insufficient. HBV DNA in such patients usually appears late, after several cycles of therapy have diminished anti-HBs to undetectable levels [6], and clinical reactivation may not occur until several years since commencing immunosuppressive 
Table 2 Risk factors associated with loss of HBV surface antibody

\begin{tabular}{|c|c|c|c|c|}
\hline & \multicolumn{2}{|l|}{ Univariate analysis } & \multicolumn{2}{|l|}{ Multivariate analysis } \\
\hline & Risk ratio $(95 \% \mathrm{Cl})$ & $p$-value & Risk ratio $(95 \% \mathrm{Cl})$ & $p$-value \\
\hline Age & $1.02(0.99-1.05)$ & 0.153 & & \\
\hline \multicolumn{5}{|l|}{ Sex } \\
\hline Female & 1 (reference) & 0.097 & & \\
\hline Male & $0.48(0.20-1.14)$ & & & \\
\hline \multicolumn{5}{|l|}{ Rheumatic disease } \\
\hline Rheumatoid arthritis & 1 (reference) & 0.582 & & \\
\hline Ankylosing spondylitis & $0.60(0.21-1.72)$ & & & \\
\hline Psoriatic arthritis/Psoriasis & $0.87(0.28-2.76)$ & & & \\
\hline Juvenile idiopathic arthritis & $2.73(0.29-25.57)$ & & & \\
\hline Anti-HBV core antigen positive & $1.23(0.51-2.95)$ & 0.641 & & \\
\hline \multicolumn{5}{|l|}{ Baseline serum anti-HBs titer (mIU/ml) } \\
\hline Lower vs higher (continuous) & $0.93(0.89-0.97)$ & 0.001 & $0.93(0.88-0.97)$ & 0.002 \\
\hline$>100$ & 1 (reference) & & 1 (reference) & \\
\hline$\leq 100$ & $46.8(10.09-\infty)$ & $<0.001$ & $43.98(9.34-\infty)$ & $<0.001$ \\
\hline \multicolumn{5}{|l|}{ Biologic DMARDs } \\
\hline Anti-TNF & 1 (reference) & 0.204 & & \\
\hline Not anti-TNF & $1.80(0.73-4.49)$ & & & \\
\hline \multicolumn{5}{|l|}{ Conventional DMARDs } \\
\hline Methotrexate & $1.00(1.00-1.00)$ & 0.942 & & \\
\hline Sulfasalazine & $1.00(1.00-1.00)$ & 0.135 & & \\
\hline Hydroxychloroquine & $1.00(1.00-1.01)$ & 0.515 & & \\
\hline Cyclosporine & $1.00(0.99-1.02)$ & 0.888 & & \\
\hline Leflunomide & $1.00(1.00-1.00)$ & 0.958 & & \\
\hline Prednisolone & $1.00(1.00-1.00)$ & 0.064 & & \\
\hline \multicolumn{5}{|l|}{ Comorbidity } \\
\hline Prior alanine transaminase elevation ${ }^{a}$ & $2.93(0.59-14.54)$ & 0.188 & & \\
\hline Hepatitis $C$ virus antibody positive & $2.64(0.54-12.92)$ & 0.232 & & \\
\hline Diabetes mellitus & $4.76(1.48-15.30)$ & 0.009 & $0.85(0.19-3.92)$ & $0.838^{\mathrm{b}}$ \\
\hline Chronic liver disease & $2.62(0.90-7.66)$ & 0.079 & & \\
\hline Chronic kidney disease & $14.00(2.22-88.23)$ & 0.005 & $45.68(2.39-871.5)$ & $0.011^{c}$ \\
\hline
\end{tabular}

Anti-HBs Hepatitis B virus surface antibody, DMARD Disease-modifying anti-rheumatic drug, TNF Tumor necrosis factor ${ }^{a}$ More than five-fold upper reference of $40 \mathrm{IU} / \mathrm{L}$

${ }^{b}$ Baseline anti-HBs as continuous variable

${ }^{\mathrm{c}}$ Baseline anti-HBs continuous + chronic kidney disease + diabetes mellitus

therapy [10-12]; median time from starting immunosuppressive therapy to HBV reactivation in a cohort of 1042 rheumatic disease patients with resolved HBV infections was 66 months [12]. However, 18/23 cases in our study had total follow-up of $<66$ months.

This is the first indication of which we know that chronic kidney disease might be a risk factor for loss of anti-HBs in patients treated with biologic DMARDs. This is an important contemporary issue because chronic kidney disease is prevalent among patients with rheumatic diseases, consequent to older age, diabetes- related nephropathy, and widespread use of nephrotoxic medications such as non-steroidal anti-inflammatory drugs or cyclosporine. Studies have shown that patients with chronic kidney disease lose anti-HBs faster than healthy subjects do [21, 22]; anti-HBs loss in chronic kidney disease or dialysis patients has been attributed to diminished interleukin-2 secretion, impaired macrophage function, decreasing memory $\mathrm{B}$ cell counts, and a weak amnestic response [23-25].

Consistent with reports of increased likelihood of antiHBs loss in patients with diabetes mellitus $[26,27]$, we 


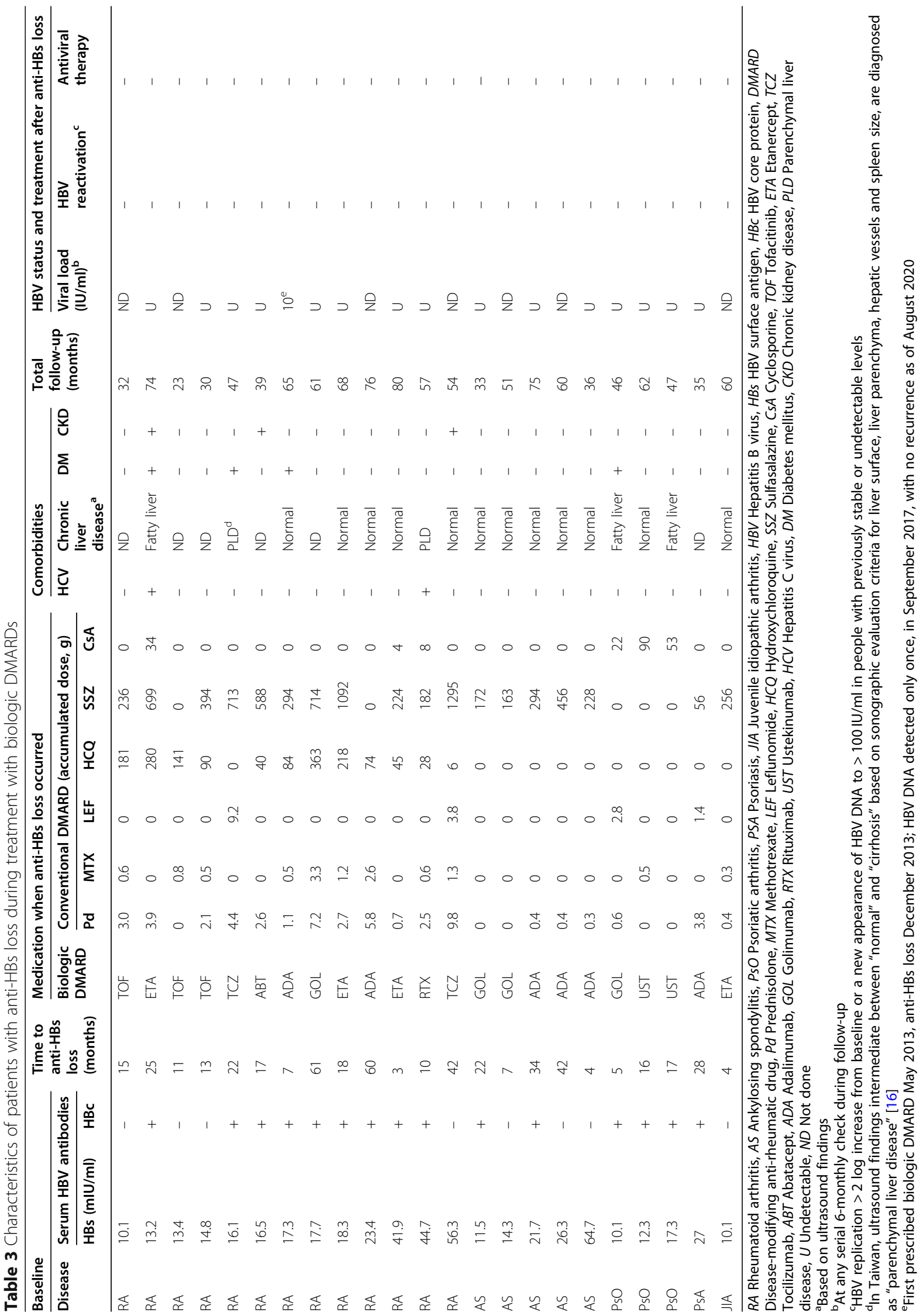


found a significant association in univariate analysis; however, statistical significance was lost in multivariate analysis, probably because only $4 / 23$ cases had diabetes.

Previous guidelines or reviews have propounded baseline anti-HBs screening prior to using biologic DMARDs, because patients with baseline anti-HBs-serostatus have higher risk of $\mathrm{HBV}$ reactivation [1, 5, 7, 8]. However, current guidelines, particularly those focused on biologic DMARDs users, neither describe nor elucidate the potential risk of anti-HBs loss during biologic DMARDs therapy $[2,5,8]$. Our results imply that there is a window of opportunity to prevent morbid HBV reactivation in patients at increased risk. We contend that clinicians should closely monitor patients with low baseline anti-HBs titer $(\leq 100 \mathrm{mIU} / \mathrm{ml})$ and/or chronic kidney disease during subsequent biologic DMARDs therapy, including followup of anti-HBs and HBV DNA titers upon anti-HBs loss, to enable timely intervention with appropriate prophylaxis to preempt potential HBV reactivation. Expert opinion supports this approach; for example, advocating HBV follow-up and immunization to reduce the risk of reactivation during anti-TNF treatment [4].

This study had limitations, foremost the small sample size. With few cases or control group patients with chronic kidney disease, the result of multivariate analysis could reflect over-fitting, as the wide confidence interval suggests; larger-scale studies are warranted to corroborate this novel but tentative finding. We acknowledge that direct serum HBV DNA assays are the ideal way to monitor patients at risk of HBV reactivation; nevertheless, based on our findings, monitoring patients with risk factors for anti-HBs loss may be a convenient and costeffective way of targeting hepatitis B prevention, especially in HBV-endemic regions. Admittedly, only direct monitoring can detect HBV reactivation due to immuneescape HBsAg mutations in anti-HBs+ biologic DMARDs recipients; however, this is a very rare phenomenon $[28,29]$ and, excepting such cases, detectable HBV DNA loads in anti-HBs+ patients otherwise occur only sporadically, and are self-limiting and clinically benign [11]. Despite considerable research into whether or not the risks of anti-HBs loss or HBV reactivation differ between biologic DMARDs, results to date have been inconclusive [30,31]; with only 23 cases, we were unable to ascertain whether individual biologic DMARDs carried similar risks of anti-HBs loss.

\section{Conclusions}

This prospective single-center study found that lower baseline anti-HBs titer $(\leq 100 \mathrm{mIU} / \mathrm{ml})$ and chronic kidney disease strongly predicted loss of anti-HBs in patients having biologic DMARDs therapy for rheumatic diseases. These insights can be applied to identify patients at increased risk of becoming anti-HBs-and monitor them for potential HBV reactivation from the onset of biologic DMARDs therapy. More research is needed to elucidate other risk factors for loss of anti-HBs and so refine the monitoring strategy to prevent $\mathrm{HBV}$ reactivation in patients receiving biologic DMARDs to treat rheumatic diseases.

\section{Abbreviations \\ HBV: Hepatitis B virus; HBsAg: HBV surface antigen; anti-HBC: Antibody to HBV core antigen; anti-HBs: Antibody to HBV surface antigen; DNA: Deoxy- ribonucleic acid; anti-TNF: Tumor necrosis factor inhibitor; DMARD: Disease- modifying anti-rheumatic drug}

\section{Acknowledgements}

David Neil, of Dr. Word Ltd., Taiwan, provided professional editorial services, which were funded by Dr Ying-Ming Chiu. Ya-Chu Yang provided technical assistance with laboratory work.

\section{Authors' contributions}

$\mathrm{MHH}$ made substantial contributions to conceiving and designing the study, analyzing and interpreting data, and drafting the manuscript. YMC made substantial contributions to conceiving and designing the study, analyzing and interpreting data, and critical revision of the manuscript for intellectually important content. YCT was involved in revising the manuscript. All authors had full control of all primary data, read and approved the final article, and agree to be accountable for all aspects of the work described.

\section{Authors' information}

Not applicable.

\section{Funding}

No specific funding was received from any funding bodies in the public, commercial, or not-for-profit sectors to carry out the work described in this report.

\section{Availability of data and materials}

The datasets used and/or analysed during this study are available from the corresponding author on reasonable request.

\section{Declarations}

Ethics approval and consent to participate

This study was performed in accordance with the ethical standards established by the 1964 Declaration of Helsinki and its later amendments. All participants provided written informed consent before any study-related procedure ensued.

Changhua Christian Hospital Institutional Review Board approved the study protocol.

\section{Consent for publication}

Not applicable.

Competing interests

The authors declare that they have no competing interests.

\section{Author details}

${ }^{1}$ Division of Allergy, Immunology and Rheumatology, Department of Internal Medicine, Changhua Christian Hospital, 135 Nanxiao St., Changhua City

500-06, Taiwan. Department of Allergy, Immunology, and Rheumatology, Tungs' Taichung MetroHarbor Hospital, 699, Sec. 8, Taiwan Blvd., Taichung City 43503, Taiwan.

Received: 29 September 2020 Accepted: 26 February 2021

Published online: 08 April 2021

\section{References}

1. Sarin SK, Kumar M, Lau GK, Abbas Z, Chan HL, Chen CJ, et al. Asian-Pacific clinical practice guidelines on the management of hepatitis B: a 2015 update. Hepatol Int. 2016;10:1-98.

2. Perrillo RP, Gish R, Falck-Ytter YT. American Gastroenterological Association Institute technical review on prevention and treatment of hepatitis B virus 
reactivation during immunosuppressive drug therapy. Gastroenterology. 2015;148:221-244.e3.

3. Di Bisceglie AM, Lok AS, Martin P, Terrault N, Perrillo RP, Hoofnagle J. Recent US Food and Drug Administration warnings on hepatitis B reactivation with immune-suppressing and anticancer drugs: just the tip of the iceberg? Hepatology. 2015:61:703-11.

4. Murdaca G, Negrini S, Pellecchio M, Greco M, Schiavi C, Giusti F, et al. Update upon the infection risk in patients receiving TNF alpha inhibitors. Expert Opin Drug Saf. 2019;18:219-29.

5. Loomba R, Liang TJ. Hepatitis B reactivation associated with immune suppressive and biological modifier therapies: current concepts, management strategies, and future directions. Gastroenterology. 2017;152: 1297-309.

6. Hoofnagle JH. Reactivation of hepatitis B. Hepatology. 2009;49(5 Suppl): S156-65.

7. European Association For The Study Of The Liver. EASL clinical practice guidelines: management of chronic hepatitis B virus infection. J Hepatol. 2012;57:167-85.

8. Koutsianas C, Thomas K, Vassilopoulos D. Hepatitis B reactivation in rheumatic diseases: screening and prevention. Rheum Dis Clin N Am. 2017; 43:133-49.

9. Su YC, Lin PC, Yu HC, Wu CC. Hepatitis B virus reactivation in patients with resolved hepatitis $B$ virus infection receiving chemotherapy or immunosuppressive therapy. Eur J Gastroenterol Hepatol. 2018;30:925-9.

10. Kuo MH, Tseng CW, Lee $\mathrm{CH}$, Tung $\mathrm{CH}$, Tseng KC, Lai NS. Moderate risk of hepatitis $\mathrm{B}$ virus reactivation in $\mathrm{HBsAg}^{-} / \mathrm{HBCAb}^{+}$carriers receiving rituximab for rheumatoid arthritis. Sci Rep. 2020;10:2456.

11. Tien YC, Yen HH, Li CF, Liu MP, Hsue YT, Hung MH, et al. Changes in hepatitis B virus surface antibody titer and risk of hepatitis $\mathrm{B}$ reactivation in $\mathrm{HBsAg-}$ negative/HBCAb-positive patients undergoing biologic therapy for rheumatic diseases: a prospective cohort study. Arthritis Res Ther. 2018;20:246.

12. Fukuda W, Hanyu T, Katayama M, Mizuki S, Okada A, Miyata M, et al. Incidence of hepatitis B virus reactivation in patients with resolved infection on immunosuppressive therapy for rheumatic disease: a multicentre, prospective, observational study in Japan. Ann Rheum Dis. 2017;76:1051-6.

13. Paul S, Dickstein A, Saxena A, Terrin N, Viveiros K, Balk EM, et al. Role of surface antibody in hepatitis $B$ reactivation in patients with resolved infection and hematologic malignancy: a meta-analysis. Hepatology. 2017;66:379-88.

14. Pei SN, Ma MC, Wang MC, Kuo CY, Rau KM, Su CY, et al. Analysis of hepatitis B surface antibody titers in B cell lymphoma patients after rituximab therapy. Ann Hematol. 2012;91:1007-12.

15. Chen YH, Chien RN, Huang YH, Chen DY, Lan JL, Lu LY, et al. Screening and management of hepatitis B infection in rheumatic patients scheduled for biologic therapy: consensus recommendations from the Taiwan Rheumatology Association. Formos J Rheumatol. 2012;26:1-7.

16. Hung CH, Lu SN, Wang JH, Lee CM, Chen TM, Tung HD, et al. Correlation between ultrasonographic and pathologic diagnoses of hepatitis B and C virus-related cirrhosis. J Gastroenterol. 2003;38:153-7.

17. Partlett C, Hall NJ, Leaf A, Juszczak E, Linsell L. Application of the matched nested case-control design to the secondary analysis of trial data. BMC Med Res Methodol. 2020;20:117.

18. Rothman KJ. Case-control studies. In: Rothman KJ, Greenland S, Lash TL, editors. Modern epidemiology. 3rd ed. Philadelphia: Williams \& Wilkins; 2008. p. 111-27.

19. Suissa S. Novel approaches to pharmacoepidemiology study design and statistical analysis. In: Strom B, editor. Pharmacoepidemiology. 4th ed. New York: Wiley; 2005. p. 811-29.

20. Dixon WG, Kezouh A, Bernatsky, Suissa S. The influence of systemic glucocorticoid therapy upon the risk of non-serious infection in older patients with rheumatoid arthritis: a nested case-control study. Ann Rheum Dis. 2011;70:956-60.

21. Buti M, Viladomiu L, Jardi R, Olmos A, Rodriguez JA, Bartolome J, et al. Long-term immunogenicity and efficacy of hepatitis $B$ vaccine in hemodialysis patients. Am J Nephrol. 1992;12:144-7.

22. Tsouchnikas I, Dounousi E, Xanthopoulou, Papakonstantinou S, Thomoglou $V$, Tsakiris D. Loss of hepatitis B immunity in hemodialysis patients acquired either naturally or after vaccination. Clin Nephrol. 2007;68:228-34.

23. Sester U, Sester M, Hauk M, Kaul H, Köhler H, Girndt M. T-cell activation follows Th1 rather than Th2 pattern in haemodialysis patients. Nephrol Dial Transplant. 2000:5:1217-23.
24. Pesanti EL. Immunologic defects and vaccination in patients with chronic renal failure. Infect Dis Clin N Am. 2001;15:813-32.

25. Descamps-Latscha B, Chatenoud L. T cells and B cells in chronic renal failure. Semin Nephrol. 1996;16:183-91.

26. Leonardi S, Vitaliti G, Garozzo MT, Miraglia del Giudice M, Marseglia G, La Rosa M. Hepatitis B vaccination failure in children with diabetes mellitus? The debate continues. Hum Vaccin Immunother. 2012;8:448-52.

27. Joo EJ, Yeom JS, Kwon MJ, Chang Y, Ryu S. Insulin resistance increases loss of antibody to hepatitis B surface antigen in nondiabetic healthy adults. J Viral Hepat. 2016;23:889-96.

28. Lazarevic I, Banko A, Miljanovic D, Cupic M. Immune-escape hepatitis B virus mutations associated with viral reactivation upon immunosuppression. Viruses. 2019;11:778

29. Westhoff $T H$, Jochimsen F, Schmittel A, Stoffler-Meilicke M, Schafer JH, Zidek W, et al. Fatal hepatitis B virus reactivation by an escape mutant following rituximab therapy. Blood. 2003;102:1930.

30. Tamori A, Koike T, Goto H, Wakitani S, Tada M, Morikawa H, et al. Prospective study of reactivation of hepatitis B virus in patients with rheumatoid arthritis who received immunosuppressive therapy: evaluation of both HBsAg-positive and HBsAg-negative cohorts. J Gastroenterol. 2011; 46:556-64.

31. Papalopoulos I, Fanouriakis A, Kougas N, Flouri I, Sourvinos G, Bertsias G, et al. Liver safety of non-tumour necrosis factor inhibitors in rheumatic patients with past hepatitis B virus infection: an observational, controlled, long-term study. Clin Exp Rheumatol. 2018;36:102-9.

\section{Publisher's Note}

Springer Nature remains neutral with regard to jurisdictional claims in published maps and institutional affiliations.
Ready to submit your research? Choose BMC and benefit from:

- fast, convenient online submission

- thorough peer review by experienced researchers in your field

- rapid publication on acceptance

- support for research data, including large and complex data types

- gold Open Access which fosters wider collaboration and increased citations

- maximum visibility for your research: over $100 \mathrm{M}$ website views per year

At BMC, research is always in progress.

Learn more biomedcentral.com/submissions 